\title{
Influence of Sources and Meteorology on Surface Concentrations of Gases and Aerosols in a Coastal Industrial Complex
}

\author{
Andrew G. Allen, ${ }^{*, a}$ Andrew J. S. McGonigle, ${ }^{b}$ Arnaldo A. Cardoso, ${ }^{a}$ Cristine M. D. Machado, ${ }^{a}$ Brian \\ Davison, ${ }^{c}$ Willian C. Paterlini, ${ }^{a}$ Gisele O. da Rocha ${ }^{d, \#}$ and Jailson B. de Andrade ${ }^{d, e}$ \\ aInstituto de Química, Universidade Estadual Paulista, CP 355, 14800-900 Araraquara-SP, Brazil \\ ${ }^{b}$ Department of Geography, University of Sheffield, Sheffield, S10 2TN, United Kingdom \\ ${ }^{c}$ Department of Environmental Science, Lancaster University, Lancaster, LA1 4YQ, United Kingdom
}

${ }^{d}$ Centro Interdisciplinar em Energia e Ambiente, Universidade Federal da Bahia, 40110-040 Salvador-BA, Brazil

${ }^{e}$ Instituto de Química, Universidade Federal da Bahia, Campus Universitário de Ondina, 40170-029 Salvador-BA, Brazil

\begin{abstract}
Emissões industriais são as fontes principais de poluição atmosférica no parque industrial de Cubatão, no sudeste do Brasil, onde a dispersão é limitada pela extensa faixa de montanhas na região. O transporte de veículos pesados é uma fonte importante de gases e aerossóis e pode influenciar nas concentrações de poluentes atmosféricos próximos à superfície, dependendo das condições meteorológicas. Este trabalho mostra que as fontes industriais foram predominantes nos fluxos de $\mathrm{SO}_{2}$, enquanto que o transporte veicular foi a principal fonte de $\mathrm{NO}_{2}$ para a atmosfera. A rápida remoção de $\mathrm{NO}_{2}$ e $\mathrm{SO}_{2}$ da atmosfera foi atribuída às reações na fase gasosa e reações heterogêneas, respectivamente. Concentrações médias de $\mathrm{MP}_{10}$ aumentaram cerca de uma ordem de magnitude durante a circulação da brisa do mar. Foi demonstrado que instrumentação de resposta rápida pode fornecer uma alternativa conveniente às medidas obtidas com equipamentos fixos para mapeamento espacial (horizontal e vertical) de poluentes atmosféricos.
\end{abstract}

Industrial emissions are a notorious source of atmospheric pollution in the Cubatão industrial park of Southern Brazil, where dispersion is restricted by surrounding mountain ranges. It is shown here that road transport is also a large source of gases and aerosols, which can dominate pollutant concentrations at ground level, depending on meteorological conditions. $\mathrm{SO}_{2}$ was released mainly by industry, while road transport was a major source of $\mathrm{NO}_{x}$. Rapid removal of $\mathrm{NO}_{2}$ and $\mathrm{SO}_{2}$ was attributed to fast gas phase and heterogeneous reactions, respectively. Average $\mathrm{PM}_{10}$ concentrations increased by an order of magnitude during sea breeze fumigation, and high particulate pollution events were associated with vehicular activity. It is demonstrated that fast-response portable instrumentation can provide a useful alternative to measurements at fixed network sites for spatial (horizontal and vertical) mapping of atmospheric pollutants.

Keywords: $\mathrm{NO}_{2}, \mathrm{SO}_{2}, \mathrm{PM}_{10}$, industry, transport, meteorology

\section{Introduction}

The metropolis of São Paulo, together with its satellite cities and the adjoining coastal strip, constitutes the largest urban-industrial complex in the southern hemisphere. Anthropogenic emissions cause near-continuous photochemical pollution, with downwind production of

*e-mail: andrew@pq.cnpq.br

\#Present Address: Instituto Multidisciplinar de Saúde, UFBA, Campus Universitário Anísio Teixeira, 45055-090, Vitória da Conquista-BA, Brazil secondary particulates and ozone. Cubatão (235 $53^{\prime} \mathrm{S}$, $46^{\circ} 25^{\prime} \mathrm{W}$ ), at sea level $40 \mathrm{~km}$ from São Paulo (760 m a.s.l.), is one of nine municipalities comprising the Baixada Santista metropolitan area (population ca. 1.5 million), and is host to the region's densest installation of heavy industry. The industrial complex includes 10 chemical and petrochemical, 7 fertilizer and 1 each of gypsum, cement, steel and paper manufacturing plants, plus approximately one hundred smaller units. Emissions inventories show that annual emissions of $\mathrm{SO}_{2}\left(c a .2 .1 \times 10^{4} \mathrm{~T} \mathrm{yr}^{-1}\right)$ and $\mathrm{NO}_{\mathrm{x}}$ (ca. $1.8 \times 10^{4} \mathrm{~T} \mathrm{yr}^{-1}$ ) from these installations are similar 
to those from industrial sources within the São Paulo metropolitan region. ${ }^{1}$ Inland dispersal of pollutants is restricted by topography, as the industrial plants are located at the base of a $c a .900 \mathrm{~m}$ coastal mountain range. During the daytime, gases and aerosols accumulate within a sea breeze circulation, while at night the ground level wind direction reverses, with heavily polluted air draining from the valleys, and air from the São Paulo plateau flowing towards the coast. The level of pollution is sufficient to cause damage to adjacent Atlantic rain forest ecosystems ${ }^{2-4}$ and human health. ${ }^{5,6}$

In this paper, we report on an observation-based evaluation of the sources, transport and dispersion of $\mathrm{SO}_{2}$, $\mathrm{NO}_{2}$ and aerosols in the Baixada Santista air basin, using open path optical spectroscopy combined with in-situ measurements.

\section{Experimental}

Field sites

Fieldwork was conducted during November $25^{\text {th }}$ $28^{\text {th }} 2004$, in and around Cubatão and the associated industrial complex, at the sites shown in Figure 1. Atmospheric column concentrations of $\mathrm{SO}_{2}$ and $\mathrm{NO}_{2}$ were measured, together with ground-level $\mathrm{NO}, \mathrm{NO}_{2}$ and aerosol number concentrations, in the lower Rio Mogi valley, $c a .1 \mathrm{~km}$ distant from the industrial installations, and upwind of emissions during down-slope airflow. Additional measurements throughout the industrial park were made with instruments installed on a car roof. Vehicle traverses under the plumes allowed calculation of the total emission fluxes of $\mathrm{NO}_{2}$ and $\mathrm{SO}_{2}$ from the complex. $\mathrm{SO}_{2}, \mathrm{NO}_{2}, \mathrm{O}_{3}$ and $\mathrm{PM}_{10}$ were measured at the São Paulo State Environment Agency (CETESB) automated network stations in central Cubatão, and in Vila Parisi, adjacent to the industrial area.

\section{$U V$-Vis spectrometer}

Atmospheric column amounts (defined as the product of concentration per unit volume and vertical depth, with units of ppm m) of $\mathrm{SO}_{2}$ and $\mathrm{NO}_{2}$ were determined using a miniature UV-Vis spectrometer (S2000, Ocean Optics Inc., USA) fibre-coupled to a telescope, providing a $20 \mathrm{mrad}$ field of view of the zenith sky. ${ }^{7-9}$ Power was delivered via USB connection to a notebook computer running Ocean Optics OOIBase 32 acquisition software. Spectral integration times varied from $1 \mathrm{~s}$ to $10 \mathrm{~s}$, depending on available light intensities, and each spectrum was georeferenced using the output from a hand held GPS receiver. The telescope

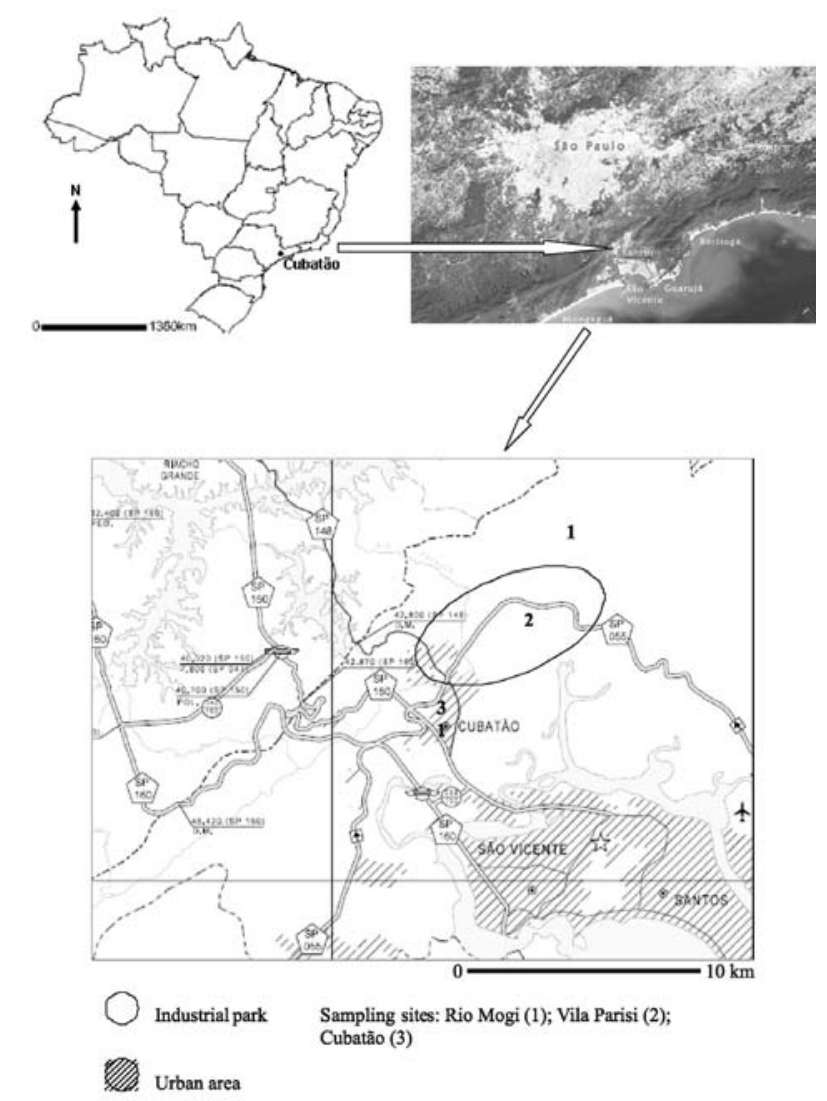

Figure 1. Map of Cubatão and surrounding region with location of sampling sites.

was attached to a vertical pole, mounted to a vehicle. Sample data were collected whilst either stationary or during mobile measurements throughout the industrial park. Vehicle speed (ca. 20-30 $\mathrm{km} \mathrm{h}^{-1}$ ) was not critical since the measurement procedure required the acquisition of geographically resolved column concentrations (rather than temporally resolved concentrations). These were calculated according to established differential optical absorption spectroscopy (DOAS) procedures, ${ }^{10,11}$ using DOASIS software (University of Heidelberg). Downwind transects at the industrial park perimeter and perpendicular to the wind direction permitted calculation of emission fluxes by integrating the column concentrations over the width of the industrial park plume, and multiplying by mean wind speed. These measurements were made at distances of 0.5-3.0 km from industrial stacks, equivalent to individual plume travel times (between the points of emission and measurement) of 2.5-25.0 minutes. Road transport-related emissions travel times were of similar order. Error in each gas emission rate measurement was estimated at $\pm 22 \%$, accounted for by $10 \%$ uncertainty in the spectral column amount retrievals, and $20 \%$ error in the wind speed determinations. 


\section{In-situ gas measurements}

Ground level concentrations of nitric oxide (NO) and nitrogen dioxide $\left(\mathrm{NO}_{2}\right)$ were determined at the Rio Mogi site by sampling ambient air, at a flow rate of $0.8 \mathrm{~L} \mathrm{~min}^{-1}$, onto two $\mathrm{C}_{18}$ silica cartridges treated with a solution of $11 \%$ triethanolamine ${ }^{15}$ and connected in series. A small glass tube containing chromium trioxide $\left(\mathrm{CrO}_{3}\right)$ glass beads, to convert $\mathrm{NO}$ to $\mathrm{NO}_{2}$, was placed in line between the two $\mathrm{C}_{18}$ cartridges. Following sample collection, the cartridges were extracted into deionized water and analyzed using the Griess-Saltzman technique. ${ }^{16}$

$\mathrm{NO}_{2}, \mathrm{SO}_{2}$ and $\mathrm{O}_{3}$ were measured at the Cubatão and Vila Parisi automatic network stations using chemiluminescence, pulsed UV fluorescence and UV absorption analyzers, respectively. ${ }^{1}$

\section{Aerosol measurements}

Aerosol number concentrations (1 minute averages), in a total of 15 size bins, were measured using a Grimm Aerosol Spectrometer (Model 1.108, Grimm Aerosol Technik GmbH, Ainring, Germany). ${ }^{7}$ In this device, ambient air was pumped at $1.2 \mathrm{~L} \mathrm{~min}^{-1}$ through a detector cell, illuminated by a semiconductor laser, generating a scattered light signal in proportion to the size of the scattering aerosol particles. Ambient temperature and humidity were measured using a Grimm Model 1.154 sensor connected to the spectrometer. Particulate mass concentrations $\left(\mathrm{PM}_{10}\right)$ were subsequently calculated from the raw counts, by assuming that the aerosols were spherical, aqueous, and had a density of $1.2 \mathrm{~g} \mathrm{~cm}^{-3}$ : a conservative estimate for ambient aerosols. ${ }^{12-14}$

$\mathrm{PM}_{10}$ mass concentrations were measured at the Cubatão and Vila Parisi automatic network stations using Thermo/ Andersen Model FH62C14 $\beta$-attenuation instruments. ${ }^{1}$

\section{Results and Discussion}

\section{Meteorology}

A high-pressure system between November $25^{\text {th }}$ and $27^{\text {th }}$ moved northwards after November $28^{\text {th }}$, following arrival of a cold front and more changeable weather with persistent rain. Daily sea breeze formation caused reversals of surface wind direction, from NNE to SSW to NNE, with the arrival of the sea breeze front in the early afternoon being signaled by an immediate decrease in visibility (due to its high aerosol content). During the evening, retreat of the circulation cell was accompanied by a return to down-slope airflow from around 20:00 pm. The depth of the local sea breeze cell in this region has been reported to be $c a .600-800 \mathrm{~m}$, and that of the nighttime down-slope flow ca. 200-300 m. ${ }^{17,18}$ Mean wind speeds, measured (under sea breeze conditions) at the Cubatão automatic network station during the periods of acquisition of data for emission flux calculations, were 2.6 $\mathrm{m} \mathrm{s}^{-1}, 2.0 \mathrm{~m} \mathrm{~s}^{-1}$ and $3.2 \mathrm{~m} \mathrm{~s}^{-1}$ on November $25^{\text {th }}, 26^{\text {th }}$ and $27^{\text {th }}$, respectively. These were similar to wind speeds estimated using time-lapse photography of stack plumes $\left(2.0-3.0 \mathrm{~m} \mathrm{~s}^{-1}\right)$ on these days, and were therefore considered representative of wind speeds to at least $50 \mathrm{~m}$ altitude. Nonetheless, since emissions flux estimates are, in part, a function of wind speed, and full vertical wind speed profiles were not available, allowance is made for possible error of $c a . \pm 20 \%$ in wind speeds used in the flux calculations.

Emission fluxes of $\mathrm{SO}_{2}$ and $\mathrm{NO}_{2}$

Fluctuations in $\mathrm{SO}_{2}$ and $\mathrm{NO}_{2}$ column concentrations measured at ground level reflected the geographical distributions of stack emissions and road traffic density. Emission flux rates calculated from data acquisitions during downwind transects (Figure 2) were $0.40 \pm 0.088 \mathrm{~kg}\left(\mathrm{SO}_{2}\right) \mathrm{s}^{-1}$ and $0.20 \pm 0.044 \mathrm{~kg}\left(\mathrm{NO}_{2}\right) \mathrm{s}^{-1}$ on November $25^{\text {th }}$, $0.71 \pm 0.14 \mathrm{~kg}\left(\mathrm{SO}_{2}\right) \mathrm{s}^{-1}$ and $0.15 \pm 0.033 \mathrm{~kg}\left(\mathrm{NO}_{2}\right) \mathrm{s}^{-1}$ on November $26^{\text {th }}$, and $0.65 \pm 0.16 \mathrm{~kg}\left(\mathrm{SO}_{2}\right) \mathrm{s}^{-1}$ and $0.03 \pm$ $0.007 \mathrm{~kg}\left(\mathrm{NO}_{2}\right) \mathrm{s}^{-1}$ on November $27^{\text {th }}$. The indicated flux ranges reflect a combined uncertainty of $\pm 22 \%$ associated with the spectrometric and wind speed measurements. Considering all measurement days, overall mean emission fluxes from the Cubatão complex were $0.59 \pm 0.13 \mathrm{~kg}$ $\left(\mathrm{SO}_{2}\right) \mathrm{s}^{-1}$ and $0.13 \pm 0.029 \mathrm{~kg}\left(\mathrm{NO}_{2}\right) \mathrm{s}^{-1}$. Annual inventory emissions from Cubatão's installations for 2004 were 20,750 $\mathrm{T} \mathrm{yr}^{-1}\left(\mathrm{SO}_{2}\right)$ and 18,340 $\mathrm{T} \mathrm{yr}^{-1}\left(\mathrm{NO}_{\mathrm{x}}\right),{ }^{1}$ equivalent to fluxes of $0.66 \mathrm{~kg}\left(\mathrm{SO}_{2}\right) \mathrm{s}^{-1}$ and $0.58 \mathrm{~kg}\left(\mathrm{NO}_{\mathrm{x}}\right) \mathrm{s}^{-1}$. The $\mathrm{SO}_{2}$ flux is in good agreement with the present estimate. The difference between the inventory $\mathrm{NO}_{\mathrm{x}}$ emission (which did not consider any contribution from road transport sources) and the measured $\mathrm{NO}_{2}$ flux can be explained by the presence of nitric oxide (NO), which was not determined, and by rapid removal of $\mathrm{NO}_{\mathrm{x}}$ by reaction (discussed below).

\section{$\mathrm{NO}_{2}$ production and removal}

$\mathrm{NO}$ is converted to $\mathrm{NO}_{2}$ at a rate dependent on factors including meteorological conditions, and ozone and hydrocarbon contents of the transported air mass. ${ }^{19,20}$ During the daytime, reactions 1-3 describe the Leighton relationship, whereby ozone is formed and recycled:

$\mathrm{NO}+\mathrm{O}_{3} \rightarrow \mathrm{NO}_{2}+\mathrm{O}_{2}$
$\mathrm{NO}_{2}+\mathrm{h} v \rightarrow \mathrm{NO}+\mathrm{O}$
$\mathrm{O}+\mathrm{O}_{2} \rightarrow \mathrm{O}_{3}$ 


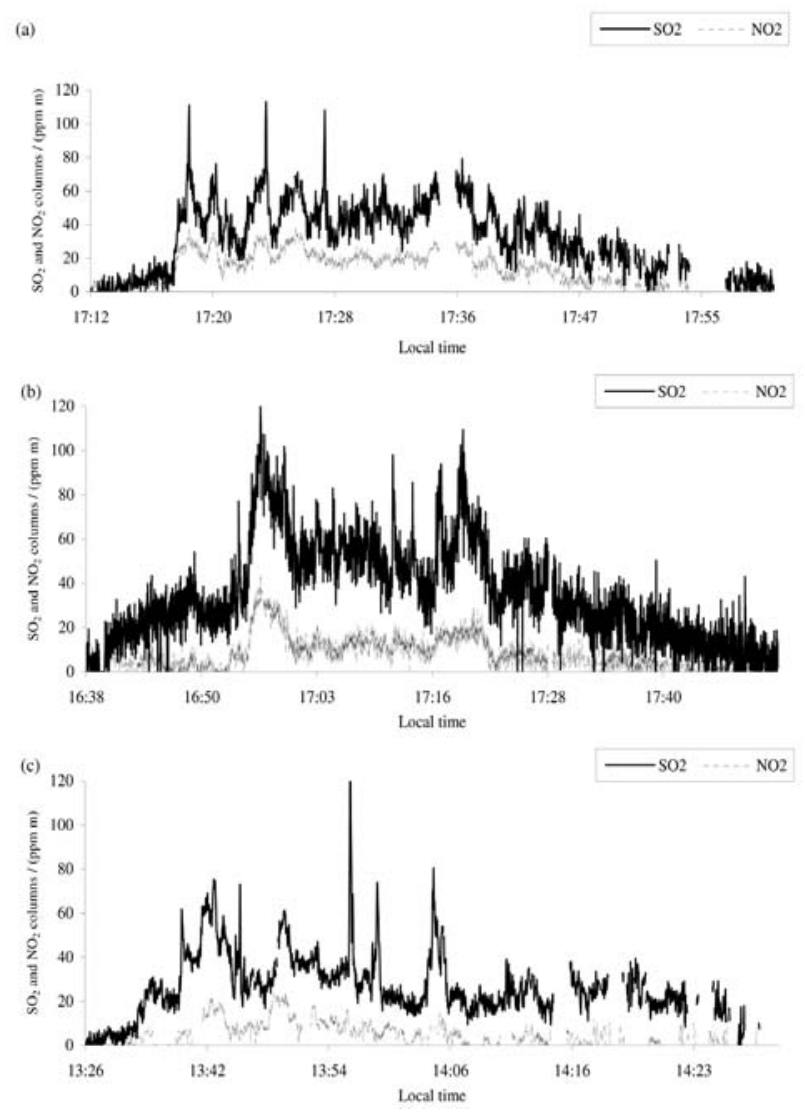

Figure 2. Vertical column concentrations of $\mathrm{SO}_{2}$ and $\mathrm{NO}_{2}$ during plume traverses on (a) November $25^{\text {th }}$, (b) November $26^{\text {th }}$, (c) November $27^{\text {th }}$.

Net $\mathrm{NO}_{2}$ production follows reaction of $\mathrm{NO}$ with the hydroperoxy and alkylperoxy free radicals formed during oxidation of organic compounds:

$\mathrm{HO}_{2}+\mathrm{NO} \rightarrow \mathrm{OH}+\mathrm{NO}_{2}$

$\mathrm{RO}_{2}+\mathrm{NO} \rightarrow \mathrm{RO}+\mathrm{NO}_{2}$

Hydrocarbon emissions of $3.46 \times 10^{4} \mathrm{~T} \mathrm{yr}^{-1}$ from road transport (derived from population and fleet statistics) and $0.39 \times 10^{4} \mathrm{~T} \mathrm{yr}^{-1}$ from industry ${ }^{1}$ should ensure an ample supply of free radical precursors, and hence the necessary conditions for rapid $\mathrm{NO}_{2}$ production. On consecutive days, there was a progressive decrease in the $\mathrm{NO}_{2}$ column concentration, relative to the $\mathrm{SO}_{2}$ column concentration; $\mathrm{NO}_{2} / \mathrm{SO}_{2}$ column ratios were $0.70,0.29$ and 0.06 on November $25^{\text {th }}, 26^{\text {th }}$ and $27^{\text {th }}$, respectively. The $\mathrm{SO}_{2}$ column concentration remained quite stable over the period, so that an explanation is required for the faster loss of $\mathrm{NO}_{2}$.

The column concentrations ratio was positively correlated with ozone and negatively correlated with relative humidity (Figure 3). The influence of ozone can be explained by the more rapid gas phase oxidation of NO by hydroperoxy and alkylperoxy free radicals, produced by reaction of ozone with hydrocarbons. There are several possible explanations for the relationship with relative humidity. Reactions removing nitrogen oxides from the atmosphere via heterogeneous processes on surfaces generate products including nitrates and nitrous acid (HONO). ${ }^{21,22}$ Experiments under controlled conditions suggest that the principal reaction could be that between water and $\mathrm{NO}_{2}$, with absorption of $\mathrm{NO}_{2}$ being dependent on the surface to volume ratio of particles possessing an aqueous surface film: $:^{23-25}$
$2 \mathrm{NO}_{2}+\mathrm{H}_{2} \mathrm{O} \rightarrow \mathrm{HONO}+\mathrm{HNO}_{3}$
$\mathrm{NO}_{2}+\mathrm{NO}+\mathrm{H}_{2} \mathrm{O} \rightarrow 2 \mathrm{HONO}$

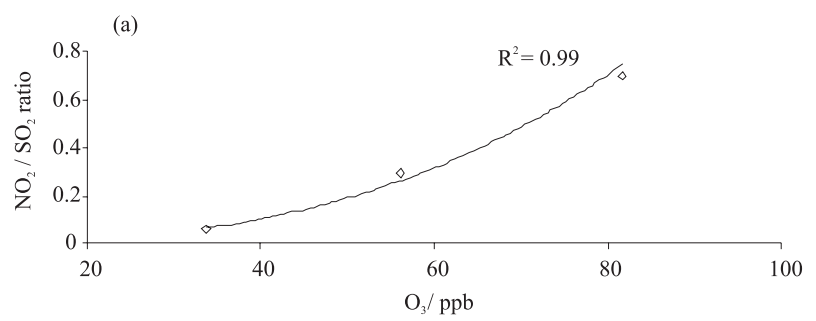

(b)

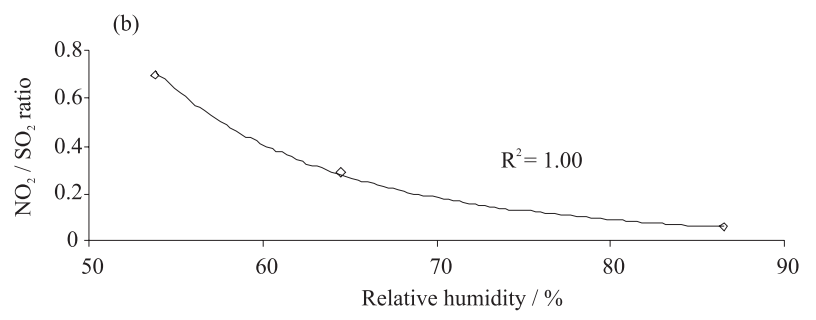

Figure 3. Relationships between $\mathrm{NO}_{2} / \mathrm{SO}_{2}$ column concentration ratios and (a) ozone and (b) relative humidity.

Hence, relative humidity has a fundamental influence on formation of the aqueous film surrounding particles, which in the presence of high number concentrations of fine pollution aerosols acts to accelerate the conversion of $\mathrm{NO}_{2}$ to nitrous acid. ${ }^{24}$ Increased relative humidity also favours analogous reactions occurring in water droplets, ${ }^{23}$ on the surfaces of soi ${ }^{25}$ and on vegetation. ${ }^{26}$ Furthermore, ozone photolysis (reactions 8,9 ) is linked to water vapour availability, with the reaction of $\mathrm{NO}_{2}$ with $\mathrm{OH}$ producing nitric acid and representing an irreversible loss of $\mathrm{NO}_{2}$ (10):

$\mathrm{O}_{3}+h v \rightarrow \mathrm{O}\left({ }^{1} \mathrm{D}\right)+\mathrm{O}_{2}$

$\mathrm{O}\left({ }^{1} \mathrm{D}\right)+\mathrm{H}_{2} \mathrm{O} \rightarrow 2 \mathrm{OH}$

$\mathrm{OH}+\mathrm{NO}_{2}+\mathrm{M} \rightarrow \mathrm{HNO}_{3}+\mathrm{M}$

It can be concluded that rapid loss of $\mathrm{NO}_{2}$ was associated with high insolation and humidity, and elevated concentrations of free radicals produced during oxidation 
of hydrocarbons. Although heterogeneous surface reactions may have also contributed to $\mathrm{NO}_{2}$ removal, a trend of decreasing aerosol surface area $\left(\mathrm{PM}_{10}\right.$ fraction) over the three sampling days suggests that gas phase reactions were most important.

\section{Aqueous phase $\mathrm{SO}_{2}$ oxidation}

Ground level $\mathrm{SO}_{2}$ concentrations (mean of all sites) during daytime fumigation were $15.2 \mathrm{ppb}$ and $2.9 \mathrm{ppb}$ on November $25^{\text {th }}$ and $27^{\text {th }}$, respectively. The much lower ground level concentration on November $27^{\text {th }}$ did not mirror either the $\mathrm{SO}_{2}$ column concentration or the industrial emission source strength (which was $0.40 \mathrm{~kg}\left(\mathrm{SO}_{2}\right) \mathrm{s}^{-1}$ on the $25^{\text {th }}$, and $0.65 \mathrm{~kg}\left(\mathrm{SO}_{2}\right) \mathrm{s}^{-1}$ on the $\left.27^{\text {th }}\right)$. A mechanism was therefore required to explain the faster $\mathrm{SO}_{2}$ loss on the $27^{\text {th }}$. Since observed $\mathrm{SO}_{2}$ column concentrations in the proximal plumes did not decline over the period (in contrast to $\mathrm{NO}_{2}$ column concentrations), elimination of $\mathrm{SO}_{2}$ was substantially slower than of $\mathrm{NO}_{2}$. Nonetheless, its removal rate increased when ozone and relative humidity increased.

Considering only reaction with the hydroxyl radical, under background atmospheric conditions $\mathrm{SO}_{2}$ and $\mathrm{NO}_{2}$ lifetimes are around 13 days and $16 \mathrm{~h}$, respectively. ${ }^{27}$ In polluted air masses, lifetimes can be much shorter, and on the order of several hours for $\mathrm{SO}_{2} \cdot{ }^{28,29}$ While gas phase reactions are important for removal of $\mathrm{NO}_{2}$, liquid phase reactions, involving ozone and hydrogen peroxide, are normally the most important reactive sink for $\mathrm{SO}_{2}$. Loss rates increase approximately in proportion to the available volume of aqueous droplets or aerosols. ${ }^{30}$ Taking into account the different daily $\mathrm{SO}_{2}$ emission fluxes, and ignoring any influence of droplet chemical composition, the difference in ground level $\mathrm{SO}_{2}$ concentrations on the two days would, in theory, require an increase of aqueous aerosol volume by a factor of $c a$. 8.5, near to the upper limit for atmospheric aerosol hygroscopic growth. ${ }^{31}$ This mechanism could not explain the $\mathrm{SO}_{2}$ loss, since aerosol volume decreased progressively throughout the consecutive sampling days, which suggests that solution chemistry and/or increased oxidant availability were the main factors influencing $\mathrm{SO}_{2}$ removal. The quantitative reduction in the ground level concentration on November $27^{\text {th }}$ means that liquid phase reactions removed $\mathrm{SO}_{2}$ on a timescale similar to that required for transport aloft of plume emissions over the coast, and return at lower altitude. Given a mean measured wind speed of $3.2 \mathrm{~m} \mathrm{~s}^{-1}$, and an air mass transport distance of $c a .30 \mathrm{~km}$, the $\mathrm{SO}_{2}$ lifetime under these conditions was $c a .2 .6 \mathrm{~h}$.
Contributions of industry and road transport to ground level $\mathrm{SO}_{2}$ and $\mathrm{NO}_{x}$

$24 \mathrm{~h}$ mean $\mathrm{SO}_{2}$ concentrations in Vila Parisi were $5.7 \mathrm{ppb}$ and $1.1 \mathrm{ppb}$ on November $25^{\text {th }}$ and $27^{\text {th }}$, respectively (no data were available for November $26^{\text {th }}$ ). $\mathrm{SO}_{2}$ concentrations in Cubatão were $9.2 \mathrm{ppb}, 5.3 \mathrm{ppb}$ and $1.5 \mathrm{ppb}$ on November $25^{\text {th }}, 26^{\text {th }}$ and $27^{\text {th }}$, respectively. Corresponding $\mathrm{NO}_{2}$ concentrations in Vila Parisi were $69.7 \mathrm{ppb}$ and 44.7 ppb, and in Cubatão were 39.9 ppb, 35.6 ppb and $21.3 \mathrm{ppb}$. Ground level afternoon concentrations of NO and $\mathrm{NO}_{2}$ at the Rio Mogi site were $0.9 \mathrm{ppb}$ and $11 \mathrm{ppb}$ on November $26^{\text {th }}$, and $1.4 \mathrm{ppb}$ and $17.2 \mathrm{ppb}$ on November $27^{\text {th }}$, demonstrating that at ground level away from the immediate vicinity of emission sources $\mathrm{NO}_{2}$ concentrations were around an order of magnitude higher than those of NO. $\mathrm{SO}_{2}$ concentrations were higher in Cubatão than in Vila Parisi, while conversely $\mathrm{NO}_{2}$ concentrations were higher in Vila Parisi. These observations can be explained by the combined influences of emission sources and meteorology, since there is intense road transport movement near the Vila Parisi site, while Cubatão is downwind of large industrial $\mathrm{SO}_{2}$ emitters, including oil refineries, during down-slope airflow towards the ocean (in the absence of the sea breeze, at night and during the morning).

In order to further investigate the relative influences of stack and ground level emissions, hypothetical atmospheric concentrations of $\mathrm{SO}_{2}$ and $\mathrm{NO}_{2}$, which would result from complete vertical mixing and homogeneity through a $700 \mathrm{~m}$ mixed layer, were calculated from the column integrated measurements (note: complete vertical mixing was not achieved in practice). The mean $\mathrm{SO}_{2}$ concentrations (ppb) thus derived were $40.3,42.2$ and 31.7 for November $25^{\text {th }}$, $26^{\text {th }}$ and $27^{\text {th }}$, respectively. The corresponding values for $\mathrm{NO}_{2}$ were 17.7, 10.5 and 5.7. These values were either higher $\left(\mathrm{SO}_{2}\right)$ or lower $\left(\mathrm{NO}_{2}\right)$ than those from the ground level monitoring stations, showing that there was a predominance of high level (stack) emissions of $\mathrm{SO}_{2}$, and ground level (road transport) emissions of $\mathrm{NO}_{\mathrm{x}}$. Correlation between $\mathrm{SO}_{2}$ and $\mathrm{NO}_{2}$ column concentrations measured throughout the industrial complex (Figure 4) results from the co-existence of strong sources of both gases in the study area, irrespective of emission altitude. However, $\mathrm{NO}_{2}$ rich columns were observed near truck parks or adjacent to the entrances of industrial facilities, where vehicular movements were especially intense. Average inventory $\mathrm{NO}_{x} / \mathrm{SO}_{2}$ concentration ratios were 24 and 1.2 for vehicle exhaust (São Paulo metropolitan area), and industrial emissions (Cubatão), respectively. A mean ground level $\mathrm{NO}_{2} / \mathrm{SO}_{2}$ ratio of 9.3 (for Vila Parisi and Cubatão) reflects the greater road transport emission of $\mathrm{NO}_{\mathrm{x}}$ relative to $\mathrm{SO}_{2}$. 
Hence, inventory estimates of $\mathrm{NO}_{\mathrm{x}}$ emissions from the Cubatão complex, which consider only industrial sources and ignore the influence of road transport, would need to be revised upwards to reflect total $\mathrm{NO}_{\mathrm{x}}$ production.

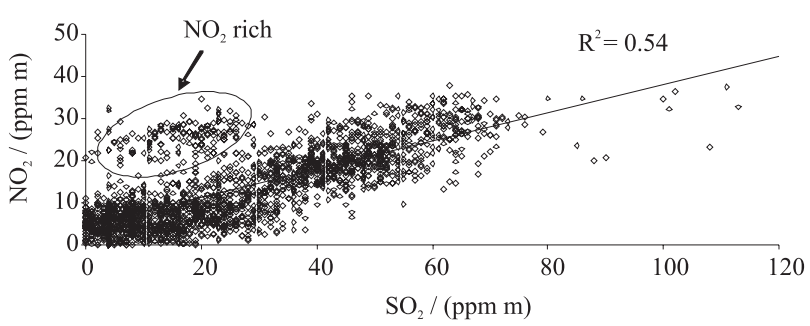

Figure 4. Scatter plot of $\mathrm{SO}_{2} v s$. $\mathrm{NO}_{2}$ column concentrations for November $25^{\text {th }}$.

Current (2008) Brazilian primary and secondary air quality standards for $\mathrm{SO}_{2}$ are $365 \mu \mathrm{g} \mathrm{m}^{-3}$ and $100 \mu \mathrm{g} \mathrm{m}^{-3}$ (equivalent to $140 \mathrm{ppb}$ and $40 \mathrm{ppb}$ ) for $24 \mathrm{~h}$ means, not to be exceeded more than once per year, and $80 \mu \mathrm{g} \mathrm{m}^{-3}$ and $40 \mu \mathrm{g} \mathrm{m}^{-3}$ (30 ppb and $15 \mathrm{ppb}$ ) for annual arithmetic means. The primary and secondary standards for $\mathrm{NO}_{2}$ are $320 \mu \mathrm{g} \mathrm{m}^{-3}$ and $190 \mu \mathrm{g} \mathrm{m}^{-3}$ (170 ppb and $100 \mathrm{ppb}$ ) for $1 \mathrm{~h}$ means, not to be exceeded more than once per year, and $100 \mu \mathrm{g} \mathrm{m}^{-3}(50 \mathrm{ppb})$ for the annual arithmetic mean. ${ }^{32}$ The measurements at the stationary sites are therefore indicative of compliance with these air quality standards.

\section{Sources of particulates}

A correlation coefficient $(r)$ of $0.79(\mathrm{n}=80, \mathrm{p}<0.01)$ was obtained between $\mathrm{SO}_{2}$ and $\mathrm{NO}_{2}$ column concentrations; however, no significant correlations were obtained between simultaneous measurements of ground level particle number concentrations, and $\mathrm{SO}_{2}$ and $\mathrm{NO}_{2}$ column concentrations, with coefficients $(r)$ of 0.00 and 0.12 $(\mathrm{n}=80, \mathrm{p}>0.1)$ obtained, respectively. The slightly higher correlation coefficient obtained between $\mathrm{NO}_{2}$ columns and aerosols (than between $\mathrm{SO}_{2}$ columns and aerosols) can be explained by co-emission of $\mathrm{NO}_{2}$ and aerosols from the road transport source. Lack of correlation between $\mathrm{SO}_{2}$ columns and aerosols reflects the existence of multiple particle sources including fugitive dust from cement and steel works, dust resuspension, vehicles and sea salt, in addition to emissions from the stacks of large combustion plants. Particles emitted from stacks arrived at ground level following transport aloft towards and over the ocean in the sea breeze circulation, and the return inland of the aerosol-laden air mass at lower altitude. Figure 5 shows the step change in aerosol number concentration at the time of first arrival of the sea breeze cell at the Rio Mogi site on November $28^{\text {th }}$.

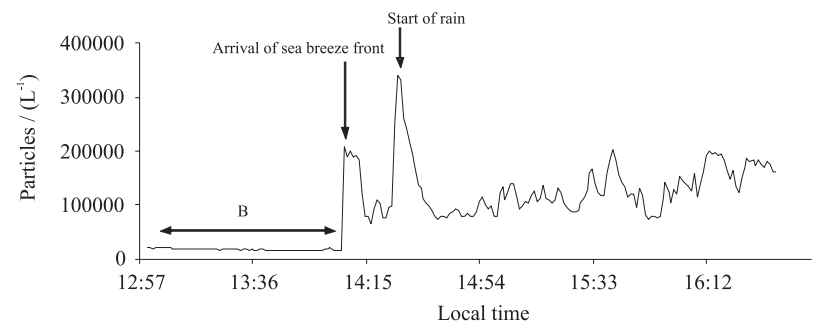

Figure 5. Total particle ( $>0.3 \mu \mathrm{m}$ ) number concentrations on November $28^{\text {th }} . \mathrm{B}=$ period of down-slope flow.

Current Brazilian $\mathrm{PM}_{10}$ standards are $50 \mu \mathrm{g} \mathrm{m}^{-3}$ (annual arithmetic mean) and $150 \mu \mathrm{g} \mathrm{m}^{-3}$ (24 h mean, not to be exceeded more than once per year). During clean down-slope flow in the Rio Mogi valley, the mean total particle number concentration was $1.7 \times 10^{4} \mathrm{~L}^{-1}$ and the mean $\mathrm{PM}_{10}$ mass concentration (conservative estimate based on a particle density of $1.2 \mathrm{~g} \mathrm{~cm}^{-3}$ ) was $3.6 \mu \mathrm{g} \mathrm{m}^{-3}$. During fumigation, mean number concentrations were $1.9 \times 10^{5} \mathrm{~L}^{-1}$ in the Mogi valley, and $7.2 \times 10^{4} \mathrm{~L}^{-1}$ in residential areas of Cubatão, approximately ten and four times higher than background, and equivalent to $\mathrm{PM}_{10}$ values of $40 \mu \mathrm{g} \mathrm{m}^{-3}$ and $15 \mu \mathrm{g} \mathrm{m}^{-3}$, respectively, similar to $24 \mathrm{~h}$ means at the Cubatão network site (33-52 $\left.\mu \mathrm{g} \mathrm{m}^{-3}\right)$. Within the industrial park, under fumigation conditions daily mean $\mathrm{PM}_{10}$ concentrations (mobile measurements) ranged between 61-195 $\mu \mathrm{g} \mathrm{m}^{-3}$, in close agreement with measurements at the fixed site in Vila Parisi (58-157 $\left.\mu \mathrm{g} \mathrm{m}^{-3}\right)$. $46 \%$ of all one-minute mean mobile $\mathrm{PM}_{10}$ measurements exceeded $50 \mu^{-3} \mathrm{~m}^{-3}$, and $14 \%$ exceeded $150 \mu \mathrm{g} \mathrm{m}^{-3}$. Locally, particulate concentrations reached extremely high levels $\left(\mathrm{PM}_{10}<4260 \mu \mathrm{g} \mathrm{m}^{-3}\right)$, notably in truck maneuvering and loading areas adjacent to industries, due to the combined contributions of sea breeze-entrained stack emissions, exhaust particulates and re-suspended dusts. These data signal a potential health concern, not only due to the high particulate mass concentrations throughout much of the industrial complex, but also because $~ 45 \%$ of the aerosol mass resided in the fine particulate fraction $(<3.5 \mu \mathrm{m})$, which can be readily inhaled and deposited in the human respiratory system. Under background conditions, the fine fraction contributed only $24 \%$ of the aerosol mass (and total mass concentrations were much lower).

\section{Conclusions}

Atmospheric pollution in the Baixada Santista region is a function of the interaction between spatially variable industrial and road transport sources, and daily fumigation induced by the geographically constricted sea breeze. There is non-uniformity in vertical gas concentration profiles, with industrial stacks releasing more $\mathrm{SO}_{2}$, and vehicles 
more $\mathrm{NO}_{\mathrm{x}}$. Very high particulate concentrations at ground level were due to vehicle activity. Emissions inventories do not currently include road transport $\mathrm{NO}_{x}$, leading to an underestimation of the total $\mathrm{NO}_{\mathrm{x}}$ emission. Accelerated chemistry in the air masses caused rapid oxidation of pollutants in gas and aerosol/droplet phases, with gas phase and heterogeneous processes predominating for $\mathrm{NO}_{2}$ and $\mathrm{SO}_{2}$, respectively.

Data from fixed network monitoring stations were generally reflective of atmospheric concentrations across this region, and can reliably provide information concerning long-term trends in pollutant concentrations. Although instruments at fixed sites may be unable to detect localized pollution, especially during periods of downslope airflow, data from these are more representative of the wider region under sea breeze conditions, when there is greater air mass mixing. Future use of directional sampling and chemical source apportionment would assist in identification of specific sources, and aid in development of mitigation strategies aiming to protect human health, especially of individuals working directly in the transport and distribution sector.

\section{Acknowledgments}

The authors thank the staff of CETESB, Cubatão, for logistical support. The work was funded by grants from CNPq, FAPESP, FUNDUNESP, FAPESB and the British Council in Brazil. AM acknowledges a RCUK academic fellowship.

\section{References}

1. CETESB; Relatório de Qualidade do Ar no Estado de São Paulo 2004, Companhia de Tecnologia de Saneamento Ambiental (CETESB), Secretaria de Estado do Meio Ambiente, ISSN 0103-4103, São Paulo, 2005.

2. Klockow, D.; Targa, H. J.; Pure Appl. Chem. 1998, 70, 2287.

3. Klumpp, A.; Domingos, M.; De Moraes, R. M.; Klumpp, G.; Chemosphere 1998, 36, 989.

4. Furlan, C. M.; Domingos, M.; Salatino, A.; Sci. Total Environ. 2007, 374, 399.

5. Spektor, D. M.; Hofmeister, V. A.; Artaxo, P.; Brague, J. A. P.; Echelar, F.; Nogueira, D. P.; Hayes, C.; Thurston, G. D.; Lippmann, M.; Environ. Health Persp. 1991, 94, 51.

6. Pereira, L. A. A.; Conceição, G. M. D.; Braga, A. L. F.; Epidemiology 2004, 15, S21.

7. Allen, A. G.; Mather, T. A.; McGonigle, A. J. S.; Aiuppa, A.; Delmelle, P.; Davison, B.; Bobrowski, N.; Oppenheimer, C.; Pyle, D. M.; Inguaggiato, S.; J. Geophys. Res. 2006, 111 (D10), Art. No. D10302.
8. McGonigle, A. J. S.; Oppenheimer, C.; Hayes, A. R.; Galle, B.; Edmonds, M.; Caltabiano, T.; Salerno, G.; Burton, M.; Mather, T. A.; J. Geophys. Res. 2003, 108 (B9), Art. No. 2455.

9. Oppenheimer, C.; Tsanev, V. I.; Allen, A. G.; McGonigle, A. J. S.; Cardoso, A. A.; Wiatr, A.; Paterlini, W.; Dias, C. M.; Environ. Sci. Technol. 2004, 38, 4557.

10. Galle, B.; Oppenheimer, C.; Geyer, A.; McGonigle, A. J. S.; Edmonds, M.; Horrocks, L.; J. Volcanol. Geotherm. Res. 2003, 119, 241.

11. Platt, U. In Air Monitoring by Spectroscopic Techniques; Sigrist, M. W., ed., Chemical Analysis Series No. 127, Wiley: NY, 1994, pp. 27-84.

12. Cross, E. S.; Slowik, J. G.; Davidovits, P.; Allan, J. D.; Worsnop, D. R.; Jayne, J. T.; Lewis, D. K.; Canagaratna, M.; Onasch, T. B.; Aerosol Sci. Technol. 2007, 41, 343.

13. Pitz, M.; Cyrys, J.; Karg, E.; Wiedensohler, A.; Wichmann, H. E.; Heinrich, J.; Environ. Sci. Technol. 2003, 37, 4336.

14. Spencer, M. T.; Shields, L. G.; Prather, K. A.; Environ. Sci. Technol. 2007, 41, 1303.

15. Ugucione, C.; Neto, J. A. G.; Cardoso, A. A.; Quim. Nova 2002, 25,353 .

16. Saltzman, B. E.; Anal. Chem. 1954, 26, 1949.

17. ENV-3; Report of the German-Brazilian Project: Air Pollution and Vegetation Damage in the Tropics-The Serra do Mar as an Example, São Paulo State Environment Secretariat, Report ENV-3, 1993.

18. Gonçalves, F. L. T.; Massambani, O.; Beheng, K. D.; Vautz, W.; Schilling, M.; Solci, M. C.; Rocha, V.; Klockow, D.; Atmos. Environ. 2000, 34, 4113.

19. Webb, A. H.; Hunter, G. C.; Environ. Pollut. 1998, 102 (S1), 283.

20. Clark, P. A. In The Chemistry and Deposition of Nitrogen Species in the Troposphere; Cocks, A. T., ed., Publication 115, Royal Society of Chemistry: Cambridge, 1993, pp. 1-22.

21. Mertes, S.; Wahner, A.; J. Phys. Chem. 1995, 99, 14000.

22. Ponche, J. L.; George, C.; Mirabel, P.; J. Atmos. Chem. 1993, $16,1$.

23. Cardoso, A. A.; Dasgupta, P. K.; Anal. Chem. 1995, 67, 2562.

24. Kleffmann, J.; Becker, K. H.; Wiesen, P.; Atmos. Environ. 1998, 12, 2721.

25. Stutz, J.; Alicke, B.; Ackermann, R.; Geyer, A.; Wang, S. H.; White, A. B.; Williams, E. J.; Spicer, C. W.; Fast, J. D.; J. Geophys. Res. 2004, 109 (D3), Art. No. D03307.

26. Zhou, X. L.; Civerolo, K.; Dai, H. P.; Huang, G.; Schwab, J.; Demerjian, K.; J. Geophys. Res. 2002, 107 (D21), Art. No. 4590.

27. Finlayson-Pitts, B. J.; Pitts, J. N. Jr.; Chemistry of the Upper and Lower Atmosphere: Theory, Experiments and Applications, Academic Press: San Diego, 2000.

28. Miyakawa, T.; Takegawa, N.; Kondo, Y.; J. Geophys. Res. 2007, 112 (D13), Art. No. D13209. 
29. Rodriguez, L. A.; Watson, I. M.; Edmonds, M.; Ryan, G.; Hards, V.; Oppenheimer, C. M. M.; Bluth, G. J. S.; J. Volcanol. Geotherm. Res. 2008, 173, 135.

30. Lamb, D.; Miller, D. F.; Robinson, N. F.; Gertler, A. W.; Atmos. Environ. 1987, 21, 2333.
31. Kandler, K; Schutz, L.; Atmos. Res. 2007, 83, 77.

32. CONAMA; Brazilian National Environment Council, Resolution CONAMA, 1990, http://www.cetesb.sp.gov.br/Ar/ ar_indice_padroes.asp, accessed in May 2008.

Received: July 7, 2008

Web Release Date: December 4, 2008

FAPESP helped in meeting the publication costs of this article. 